\title{
Strategy to Improvement Sustainability of Distinctively Local Snacks Based on Evaluation and Profile Mapping of SMEs Distinctively Local Snacks
}

\author{
Yulia Nurendah \\ STIE Kesatuan Bogor, Bogor, 16123, West Java, Indonesia \\ E-mail: lia_niceone@yahoo.com
}

\begin{abstract}
SMEs (IKM) snacks include in group industries which develop quite progressively in Indonesia. There are typical regional food or local food specialties which have been distinctively long-grown specifically in an area;however, there are also some food specialties which are area-based potentially developed. Therefore, efforts to develop and empower SMEs (IKM) distinctively local snacks should be done to be able to increase its competitiveness in facing the globalization and the free market. The objective of Profile Mapping of SMEs (IKM) is that the development of distinctively local snacks can be implemented in an integrated, focused way, and on target. If SMEs (IKM) snacks get special attention with the pattern of development and directed policy, it will become the backbone of the rise of the real sector in the region. The study of profile mapping of SMEs (IKM) distinctively local snacks is conducted by combining descriptive research method based on the results of field surveys combined with SWOT analysis Data processing and analysis with Profile Mapping of SMEs (IKM) Snacks, Performance Analysis and Competitive Strategy of SMEs (IKM) Snacks, SWOT Analysis, Strategy and Feasibility and concept Development models of SMEs (IKM) Snacks. Bakpia becomes a top priority as a superior snack product from Jogjakarta (DIY), which can be further developed in the process of production and marketing. The attributes of main and additional ingredients, water supply, and production tools are still in average performance. In this case, the performance measure is based on the perception of bakpia producers in medium scale, while there are expectations on a high scale. Thus, there needs to be an increase in these attributes. After knowing the score of IFA, then a right strategy to be applied for SMEs (IKM) position is a strategy of growth through horizontal integration which is an activity to expand SMEs (IKM) by building in another location and increasing the variety of products and services. When referring to the SWOT matrix, there are several strategies that can be done in developing SMEs (IKM) food products in the province of Jogjakarta.
\end{abstract}

Keywords — Evaluation; Profile Mapping; SMEs (IKM) Snacks; Jogjakarta

\section{INTRODUCTION}

This Small and Medium Industrial Sectors (SMI) is a significant driving force for the development of Indonesia's economy, particularly in the development of economy and employment. There were as many as 4,026,624 SMI business units nationwide in 2012 with the employment rate amounted to $9,462,565$ people (54.6\% of total workforce) (BPS, 2013). SMIs development is inseparable from the commitment, policies, and government programs, with the aim that SMIs can continue to grow and be competitive so that they can compete in the global economy.

SMI snacks are included in the industry group whose development is quite progressive in Indonesia. Various regions in Indonesia have been known to have their own characteristics including their regional specialties.
Therefore, the development efforts and empowerment of SMI distinctively local snacks should continue to be done in order to be able to increase its competitiveness in the era of globalization and free markets.

The goal is for the development of SMEs distinctively local snacks in order to be implemented integratedly, effectively, and well targeted

\section{MATERIAL AND METHODS}

\section{A. All The framework}

In general, the framework used in this study is presented in Fig. 1.

\section{B. Data Analysis and Research :}

Profile mapping of SMI snacks; Performance Analysis and Competitive Strategy of SMI Snacks; SWOT analysis; 
and Feasibility Strategy and Model Concept of the IKM Snacks Development

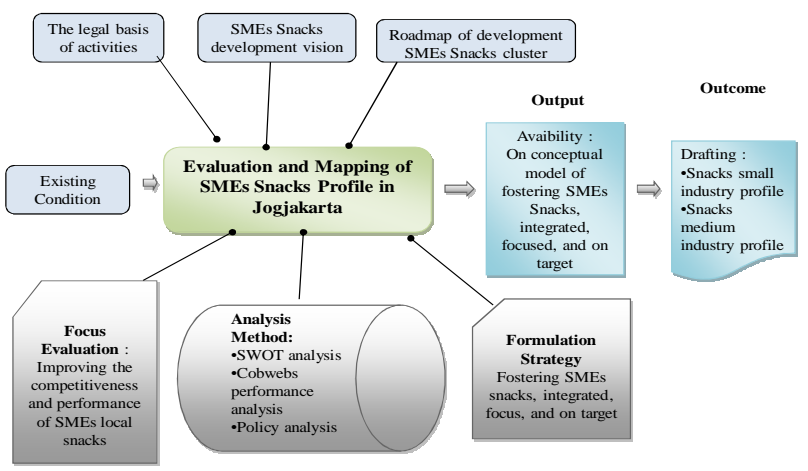

Fig. 1 The Framework Mapping of SMI Snack Profile

\section{RESULTS AND DISCUSSION}

\section{A. The Small Industry (SI) Snacks in Yogyakarta}

\section{1) Excellent Products of SI Snacks in Yogjakarta}

The food industry in Yogyakarta grows well and varied. Some of very interesting foods that can always be enjoyed: Bakpia Pathok, Geplak, Yangko. Results of the evaluation of the determination of Yogyakarta excellent snack products based on five attributes are presented in Fig. 2.

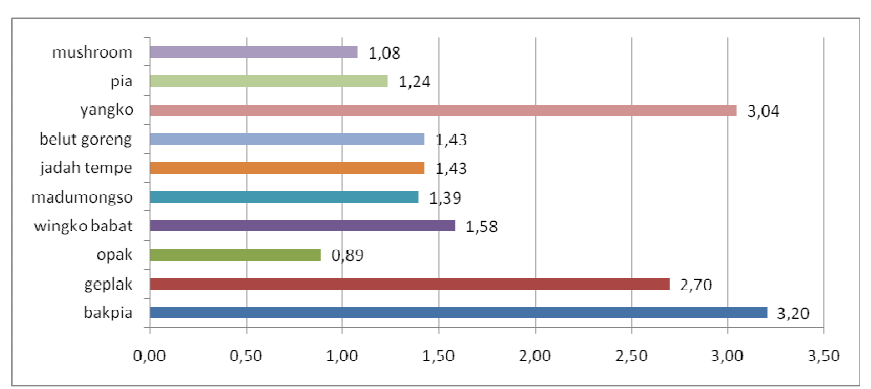

Fig. 2 Comparison of weight determination of the excellent products of small industries in Yogyakarta snacks

Based on Fig. 2 it is known that bakpia gets the highest position with weights $3: 20$. In this case, it can be said that for small industries, bakpia is an excellent product.

\section{2) Performance of SI Snacks in Yogjakarta}

The results of peformance measurement is shown in Fig. 3.

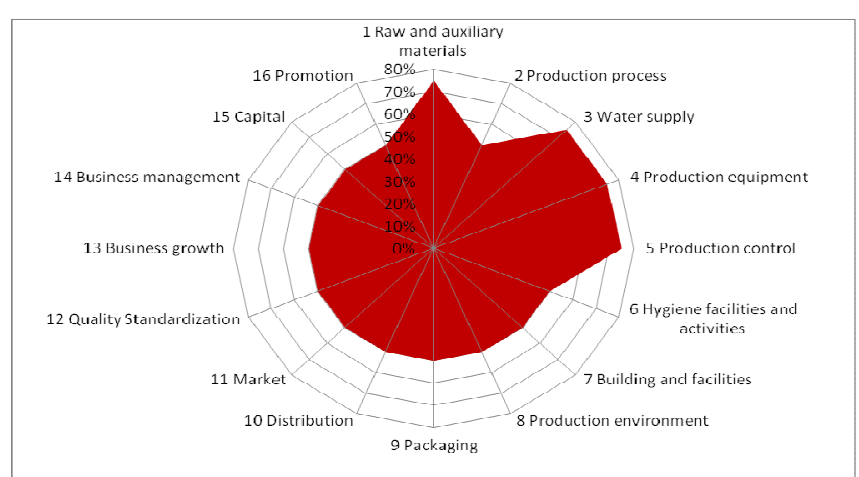

Fig. 3 Spider Diagram of performance achievement of IM food in Yogjakarta
Based on Fig. 3 it can be seen that for the attributes of raw and additive materials, water supply, production equipment and production control, it has moderate performance. In this case, the measure of performance based on the perception of industry players is in the medium scale, while the expectation is on a high scale. Thus, there needs to be an increase in these attributes. Development of small industries (SI) snacks bakpia in Yogyakarta refers to existing condition profile, needs, and local regulations applied. Based on the mapping performance presented in Fig. 4.

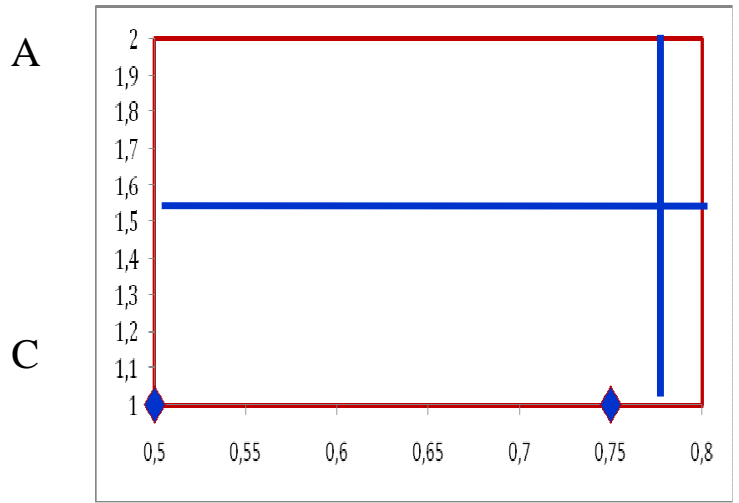

B

D

Fig. 4 Attribute performance of SI food products in Yogyakarta

The problems can be seen, as follows: (1) the weakness in the form of a gap on most of its attributes; (2) the competitive advantage of SI food rests on the comparative advantages; and, (3) the type of assistance from the goverrment/related institutions are relatively more oriented to the type of assistance that is charged on the economic content instead of knowledge content, so that the positive impact is perceived onlyin a short-term.

\section{3). Development Model of SI Snacks in Yogjakarta}

The local government has a very high concern in conducting guidance to SMIs' Bakpia which is an excellent product of small industrial snacks in Yogyakarta requiresa better fostering in terms of the production process and production facilities in the form of equipment and training assistance to produce more higher-quality products.

Besides, it also needs a guidance in terms of packaging in order to compete with other products when exported. It is also important to provide the assistance in the development of market share both domestically and abroad. Moreover, the development aid in the promotion of development is needed as well so that the products will be more widely known.

\section{B. Intermediate Industri (IM) of Snacks in Yogjakarta \\ 1). The excellence of IM Snacksfrom Yogjakarta}

The products that become excellent snacks in Yogjakarta based on five attributes is displayed in Fig. 5 


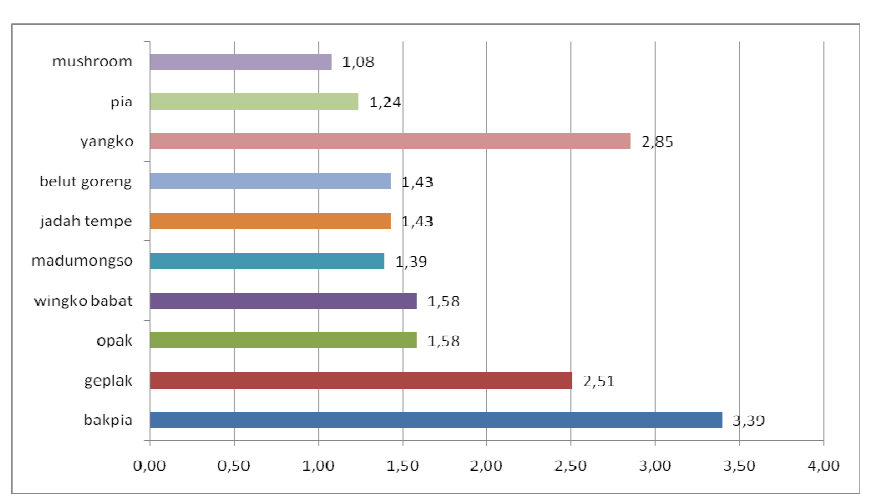

Fig. 5 Comparison of weight determination of the excellent product of IM food in DI Yogyakarta

Based on Fig. 5 it is known that bakpia gets the highest position with the weights $3: 29$, in this case, it can be said that for intermediate industries, bakpia is an excellent product.

\section{2). The Performance of IM Snacks in Yogjakarta}

The results of performance measurement is as shown in Fig. 6. and Fig. 7

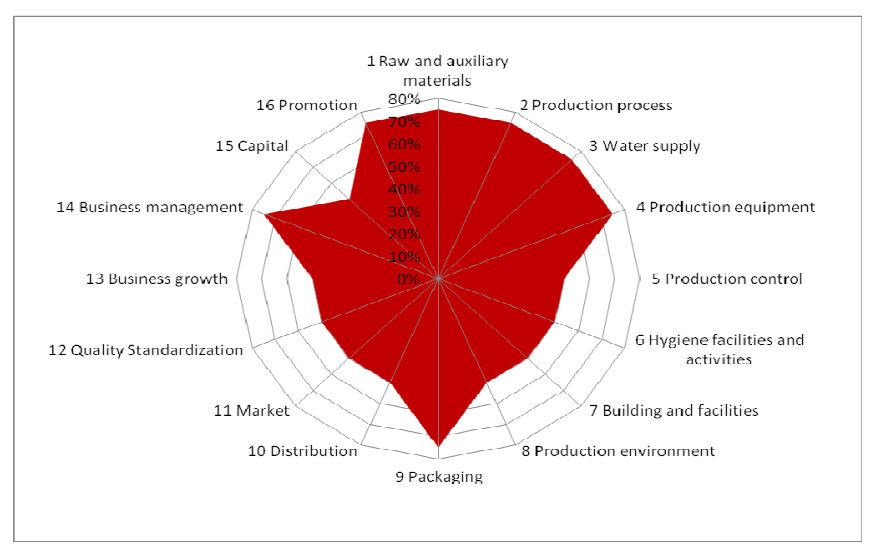

Fig. 6 Spider Diagram of performance achievement of IM food inYogjakarta

Based on Fig. 6 it is known that for the attributes of raw and additive materials, water supply, production equipment and production control, it has moderate performance. In this case, a measure of performance based on the perception of industry players in the medium scale, while the expectation is on a high scale. Thus, there needs to be an increase in these attributes.

Based on the performance mapping in Fig. 7 it is visible that there are some problems, as follows: (1) the weakness in the form of a gap on most of its attributes; (2) the competitive advantage of IM is based on comparative advantage; and, (3) the type of assistance from the relevant government is relatively more oriented to the type of assistance that is charged on the economic contentinstead of knowledge content, so that the positive impact is perceived only in a short-term.

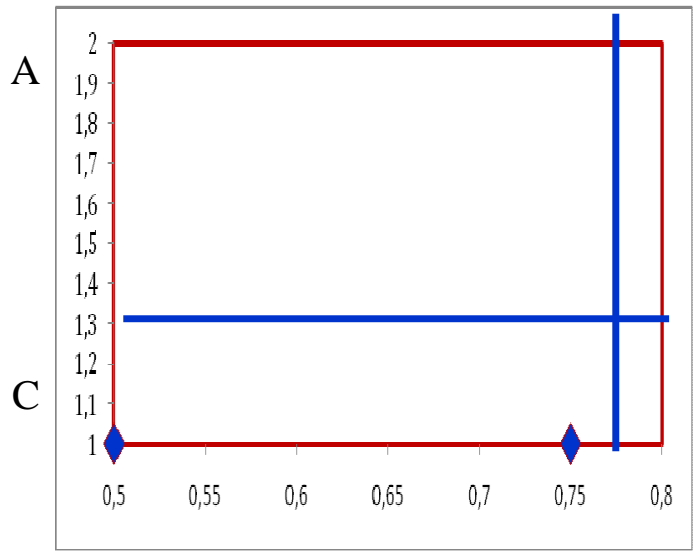

B

Fig. 7 Attribute Performance IM Food Products in Yogjakarta

\section{3). Development Model of IM Snacks in Yogjakarta}

The local government has a very high concern in conducting guidance to SMIs' Bakpia which is an excellent product of small industrial snacks in Yogyakarta requiresa better fostering in terms of the production process and production facilities in the form of equipment and training assistance to produce more higher-quality products.

Besides, it also needs a guidance in terms of packaging in order to compete with other products when exported. It is also important to provide the assistance in the development of market share both domestically and abroad.

Moreover, the development aid in the promotion of development is needed as well so that the products will be more widely known.

\section{Development Strategy of SMI Snacks in Yogjakarta}

The result of SWOT analysis of IK bakpia snack Yogjakarta is as displayed in Table 1 and Table 2. Fig. 8 displayed internal and external matrix. Fig. 9 displayed space matrix source.

TABLE I

STRATEGIC ANALYSIS OF INTERNAL FACTOR (IFAS) OF IK YOGJAKARTA

\begin{tabular}{|c|c|c|c|}
\hline Internal Strategic Factor & Weight & Rate & Score \\
\hline Strengths & 0.5 & & \\
\hline $\begin{array}{l}\text { Travelers who visit jogja } \\
\text { definitely look for food } \\
\text { souvenirs }\end{array}$ & 0,15 & 4 & 0,60 \\
\hline $\begin{array}{l}\text { 2. Bakpiais a typical food } \\
\text { fromJogja }\end{array}$ & 0,20 & 4 & 0,8 \\
\hline $\begin{array}{l}\text { 3. Bakpiacan be preserved up to } 1 \\
\text { week }\end{array}$ & 0,15 & 3 & 0,45 \\
\hline $\begin{array}{l}\text { 4. Lots of taste and affordable } \\
\text { price }\end{array}$ & 0,10 & 3 & 0,30 \\
\hline Weaknesses & 0.5 & & \\
\hline $\begin{array}{l}\text { 1. Many obstacles in seeking } \\
\text { consumers and marketing }\end{array}$ & 0,15 & 2 & 0,3 \\
\hline 2. The filling is slightly & 0,10 & 2 & 0,2 \\
\hline $\begin{array}{l}\text { 3. If this food is not sold, it can } \\
\text { be stale }\end{array}$ & 0,05 & 1 & 0,05 \\
\hline $\begin{array}{l}\text { 4. Not having a good production } \\
\text { equipment }\end{array}$ & 0,20 & 1 & 0,20 \\
\hline & 1,0 & & 2,9 \\
\hline
\end{tabular}

Interpretation : Based on IFAS matrix above, the score valueobtained is about 2, 90 
TABLE II

STRATEGIC ANALYSIS OF EXTERNAL FACTOR (EFAS) OF IK YOGJAKARTA

\begin{tabular}{|c|c|c|c|}
\hline External Strategic Factor & Weight & Rate & Score \\
\hline Opportunities & 0,5 & & \\
\hline $\begin{array}{l}\text { 1. The production of this food is } \\
\text { not too difficult }\end{array}$ & 0,15 & 4 & 0,6 \\
\hline $\begin{array}{l}\text { 2. There are not many of bakpia } \\
\text { employers using online bakpia } \\
\text { business }\end{array}$ & 0,10 & 4 & 0,4 \\
\hline $\begin{array}{l}\text { 3. This business does not need } \\
\text { too big capital }\end{array}$ & 0,15 & 4 & 0,6 \\
\hline $\begin{array}{l}\text { 4. There are many tourists who } \\
\text { visitDI Yogjakarta }\end{array}$ & 0,05 & 3 & 0,15 \\
\hline $\begin{array}{l}\text { 5. The preservation of this food } \\
\text { can be more durable }\end{array}$ & 0,05 & 3 & 0,15 \\
\hline Threats & 0,5 & & 0 \\
\hline $\begin{array}{l}\text { 1. Business competitors who } \\
\text { have reguler customers }\end{array}$ & 0,35 & 2 & 0,7 \\
\hline $\begin{array}{l}\text { 2. There are many of these } \\
\text { businesses that go bankrupt }\end{array}$ & 0,35 & 2 & 0,7 \\
\hline $\begin{array}{l}\text { 3. If this food is not sold, it can } \\
\text { be stale }\end{array}$ & 0,30 & 1 & 0,30 \\
\hline & 1,0 & & 3.6 \\
\hline
\end{tabular}

Interepretation: Based on the EFAS matrix above, the score valueobtained is about3.6

Total Score of Internal Factors

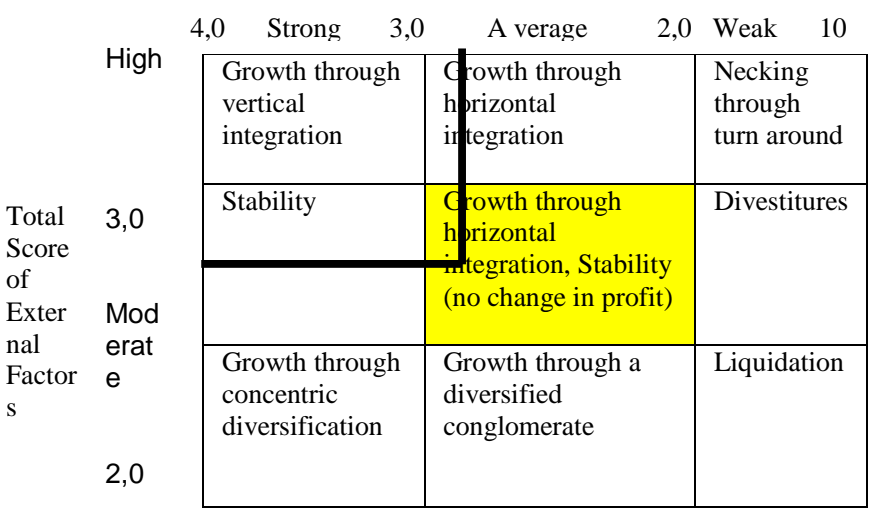

Fig. 8 Internal and External Matrix

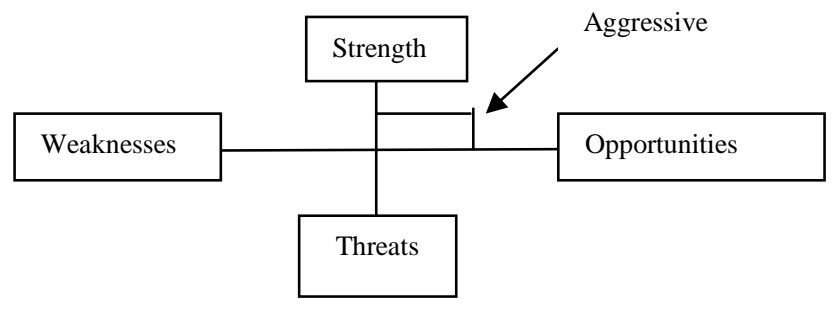

Fig. 9 Space Matrix Source

After knowing the IFAS score value about 2,9 and EFAS score value about 3,6,so Matrik Internal - External (IE Matrix) is obtained. Based on the above conditions in which the score of IFAS is relatively above average and EFAS score is medium, the proper strategy applied for the position of IK is the strategy of growth through horizontal integration which is an activity to expand IK by making the similar business in another location and increase the types of products as well as the services. If IK is in moderate attractive industry, the strategy applied is consolidation. Table .3 explains the result of identification in SWOT analysis and the strategies that can be taken. The result of SWOT analysis for IM snacks in Yogjakarta is as displayed on Table 4 and Table 5 Fig. 10 displayed internal and external matrix. Fig. 11 displayed space matrix source.

TABLE III

SMES DEVELOPMENT STRATEGIES For BAKPIA SNACK IN YOGJAKARTA BASED ON RESULTS OF SWOT ANALYSIS

\section{\begin{tabular}{|l|l}
\hline S-O STRATEGIES & W-O STRATEGIES
\end{tabular}}

1. Aggressive strategy to increase the market share.

2. Improving marketing in new markets.

3. Improving the operational efficiency

S-T STRATEGIES

1. Improving the quality and quantity of marketing.

2. Implementing the marketing strategy of "proactive" especially to new markets

1. The operational efficiency.

2. The production machinery investment cooperation with various parties.

3. Improving the quality of service to consumers.

W-T STRATEGIES

1. Development of a new service network.

2. Development of bakpia in production systems/operations

TABLE IV

STRATEGIC ANALYSIS OF INTERNAL FACTOR (IFAS) OF IM YOGJAKARTA

\begin{tabular}{|c|c|c|c|}
\hline Internal Strategic Factor & Weight & Rate & Score \\
\hline Strengths & 0.5 & & \\
\hline $\begin{array}{l}\text { 1. Travelers who visit jogja definitely } \\
\text { look for food souvenirs }\end{array}$ & 0,15 & 4 & 0,60 \\
\hline 2. Bakpia is a typical food of Jogja & 0,15 & 4 & 0,60 \\
\hline $\begin{array}{l}\text { 3. The quality of the Special Region of } \\
\text { Yogyakarta snacks are generally } \\
\text { better than the products from other } \\
\text { regions }\end{array}$ & 0,10 & 4 & 0,40 \\
\hline 4. Labors areeasily obtainable. & 0,05 & 3 & 0,15 \\
\hline $\begin{array}{l}\text { 5. Most of the products are oriented on } \\
\text { local, national, and export markets }\end{array}$ & 0,05 & 3 & 0,45 \\
\hline Weaknesses & 0.5 & & \\
\hline 1. A little content & 0,05 & 2 & 0,10 \\
\hline 2. If it is not sold, this food can be stale & 0,05 & 2 & 0,10 \\
\hline 3. The old production machine & 0,15 & 1 & 0,30 \\
\hline $\begin{array}{l}\text { 4. The price of local products is less } \\
\text { competitive than the price of similar } \\
\text { products }\end{array}$ & 0,10 & 1 & 0,10 \\
\hline \multirow[t]{2}{*}{$\begin{array}{l}\text { 5. The proportion of imported raw } \\
\text { materials is likely increasing }\end{array}$} & 0,05 & 1 & 0,05 \\
\hline & 1,0 & & 2,85 \\
\hline
\end{tabular}

Interpretation: Based on IFAS matrix above, the score valueobtained is about 2,85

TABLE V

STRATEGIC ANALYSIS OF IXTERNAL FACTOR (EFAS) OF IM YOGJAKARTA

\begin{tabular}{|l|c|c|c|}
\hline External Strategic Factor & Weight & Rate & Score \\
\hline Opportunities & $\mathbf{0 , 5}$ & & \\
\hline 1. The production of this food is not too difficult & 0,20 & 4 & 0,80 \\
\hline $\begin{array}{l}\text { 2. There are not many of bakpia employers using } \\
\text { online bakpia business }\end{array}$ & 0,15 & 4 & 0,60 \\
\hline $\begin{array}{l}\text { 3. Implementing the programs of giving machinery } \\
\text { assistance }\end{array}$ & 0,15 & 4 & 0,60 \\
\hline 4. Tax relief & 0,20 & 3 & 0,60 \\
\hline 5. Requested products that are likely increasing & 0,10 & 3 & 0,30 \\
\hline Threats & $\mathbf{0 , 5}$ & & \\
\hline $\begin{array}{l}\text { 1. business competitors who have regular } \\
\text { customers }\end{array}$ & 0,05 & 1 & 0,05 \\
\hline 2. The food is not durable & 0,05 & 2 & 0,10 \\
\hline $\begin{array}{l}\text { 3. The decrease of Indonesian people's } \\
\text { consumption on snacks }\end{array}$ & 0,02 & 2 & 0,04 \\
\hline 4. Similar Items control 20-30\% share & 0,05 & 1 & 0,05 \\
\hline $\begin{array}{l}\text { 5. business competitors who have regular } \\
\text { customers }\end{array}$ & 0,03 & 2 & 0,06 \\
\hline & 1,0 & & 3,20 \\
\hline
\end{tabular}

Intrepretation: Based on EFAS matrix above, the score valueobtained is about 3,20 


\begin{tabular}{|c|c|c|c|c|}
\hline & & Total Score & f Internal Factors & \\
\hline & Hiah & $4,0 \quad$ Strong & Average & Weak \\
\hline $\begin{array}{l}\text { Total } \\
\text { Score }\end{array}$ & & $\begin{array}{c}\text { Growth } \\
\text { through } \\
\text { vertical } \\
\text { integration }\end{array}$ & $\begin{array}{l}\text { G owth through } \\
\text { horizontal } \\
\text { integration }\end{array}$ & $\begin{array}{l}\text { Necking } \\
\text { through turn } \\
\text { around }\end{array}$ \\
\hline $\begin{array}{l}\text { Exter } \\
\text { nal } \\
\text { Fac } \\
\text { tors }\end{array}$ & $\begin{array}{l}\text { Mod } \\
\text { erate }\end{array}$ & Stability & $\begin{array}{c}\text { Growth through } \\
\text { horizontal } \\
\text { integration, Stability } \\
\text { (no change in profit) }\end{array}$ & Divestitures \\
\hline & 2,0 & $\begin{array}{c}\text { Growth } \\
\text { through } \\
\text { concentric } \\
\text { diversification }\end{array}$ & $\begin{array}{l}\text { Growth through a } \\
\text { diversified } \\
\text { conglomerate }\end{array}$ & Liquidation \\
\hline
\end{tabular}

Fig. 10 Internal and External Matrix

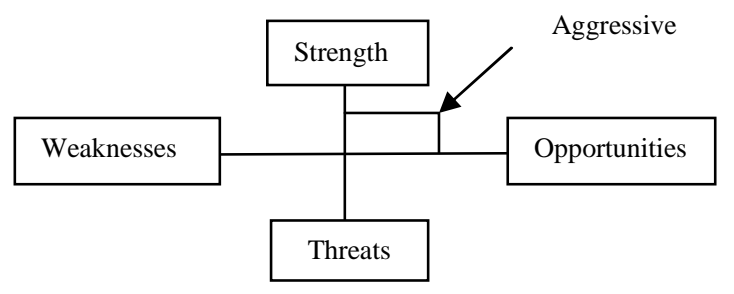

Fig. 11 Space Matrix Source

After knowing the score value of IFAS about 2,85 and the score valueof EFAS about 3,20, so Internal - External Matrix (IE Matrix) is obtained. Table 6 describes the identification of a SWOT analysis and a strategy that can be taken in IM bakpia snacks from Yogyakarta.

TABLE VI

SMES DEVELOPMENT STRATEGIES For BAKPIA SNACK IN YOGJAKARTA BASED ON RESULTS OF SWOT ANALYSIS

\begin{tabular}{|c|c|}
\hline $\begin{array}{l}\text { S-O STRATEGIES } \\
\text { 1. Aggressive strategy to } \\
\text { increase the market share. } \\
\text { 2. Improving marketing in new } \\
\text { markets. } \\
\text { 3. Improving the operational } \\
\text { efficiency }\end{array}$ & $\begin{array}{l}\text { W-O STRATEGIES } \\
\text { 1. The operational } \\
\text { efficiency. } \\
\text { 2. The production machinery } \\
\text { investment cooperation } \\
\text { with various parties. } \\
\text { 3. Improving the quality of } \\
\text { service to consumers. }\end{array}$ \\
\hline $\begin{array}{l}\text { S-T STRATEGIES } \\
\text { 1. Improving the quality and } \\
\text { quantity of marketing. } \\
\text { 2. Implementing the marketing } \\
\text { strategy of "proactive" } \\
\text { especially to new markets }\end{array}$ & $\begin{array}{ll}\text { W-T STRATEGIES } \\
\text { 1. } \\
\text { Development of a new } \\
\text { service network. } \\
\text { 2. } \\
\text { evelopment of bakpia in } \\
\text { production } \\
\text { systems/operations. }\end{array}$ \\
\hline
\end{tabular}

\section{CONCLUSIONS}

Bakpia becomes a top priority as a superior snack product from Jogjakarta (DIY), which can be further developed in the process of production and marketing. The attributes of main and additional ingredients, water supply, and production tools are still in average performance. In this case, the performance measure is based on the perception of bakpia producers in medium scale, while there are expectations on a high scale. Thus, there needs to be an increase in these attributes. After knowing the score of IFA, then a right strategy to be applied for SMEs (IKM) position is a strategy of growth through horizontal integration which is an activity to expand SMEs (IKM) by building in another location and increasing the variety of products and services. When referring to the SWOT matrix, there are several strategies that can be done in developing SMEs (IKM) food products in the province of Jogjakarta.

\section{REFERENCES}

[1] Biro Pusat Statistik. Profil Industri Mikro dan Kecil. Jakarta 2013

[2] Biro Pusat Statistik. Profil Industri Mikro dan Kecil. Berita Resmi Statistik No. 31/05/ Th. XVI, 1 Mei 2013

[3] Biro Pusat Statistik. Profil Industri Mikro dan Kecil. Jakarta 2014

[4] Direktorat Jenderal Industri Kecil dan Menengah Kementerian Perindustrian RI. Wirausaha Industri. Paket Informasi Kebijakan. Jakarta. 2013

[5] Lembaga Pengelola Dana Bergulir KUMKM. Rencana Strategis Bisnis LPDB KUMKM, Jakarta 2014

[6] Ranadireksa. Gudang Pangan Tujuan Wisata Paru-Paru Dunia. PT. Permata Artistika Kreasi. Jakarta. 2000.

[7] Thaheer. Sistem Manajemen HACCP. Bumi Aksara. Jakarta 2005.

[8] Yuasa Food Berkah Makmur. Company Profile. Wonosobo. 2013 